\title{
DAMAGE IN CHRISTCHURCH AND CANTERBURY
}

\author{
P. J. Moss*
}

\section{Introduction}

For many people in Christchurch and other parts of Canterbury, the earthquake which occurred in the early hours of 24 th May was marked by considerable shaking which lasted for about 35 seconds. In many cases the shaking was accompanied by some noise as the house moved with the earthquake. However, later conversation indicated that some people, at least, claimed that they were not woken at all by the earthquake and so showed that the earthquake was not very severe.

Initial newspaper reports showed that a little damage had been caused to commercial buildings in Christchurch - mainly cracked brickwork and plaster. The Lyttelton road and railway tunnels were undamaged, as were all railway bridges in Canterbury. No damage was reported from Timaru, Ashburton or other areas in South Canterbury.

Shortly after the earthquake it was noticed that the cross on the top of the Cathedral spire was moving as the bells were rung. Since two previous crosses had been damaged by earthquakes, earthquake damage was again suspected. Later examination showed however that the movement was due to the effects of weathering and time。

\section{The extent of damage}

Damage was light throughout the whole of the Canterbury area. The number of claims from the area handled by the Earthquake and Var Damage Commission was as 10 as 600 compared with the several thousand that resulted from the April storm damage. Of the 600 claims, some $60 \%$ were for damage to chimneys. The remainder were mainly for cracking to walls and foundations, as well as roof damage.

In general, light damage occurred throughout North Canterbury while there was very little damage in South Canterbury. In addition to those areas shown in figure 1, some damage occurred in the area extending up to 20 miles south and soutwest of Christchurch. Rangiora, 20-25 miles north of Christchurch appears to have been almost free from damage while areas further north were affected。 Culverden and Waikari were damaged more extensively than Cheviot which has suffered considerable damage in previous earthquakes。

Few multistorey buildings exist in areas outside Christchurch. The damage to houses here was much the same in type as that which occurred in Christchurch. This included damage to chimneys (mainly double chimneys), roofs and ceilings (particularly around the chimney breast), and cracking of lathe and plaster walls and ceilings.

\section{Damage in the Christchurch area}

A rough analysis of the damage is given in Table 1 .

In the Christchurch area, damige appears to have been confined to houses and the older masonry buildings. Damage was scattered throughout

+ Lecturer, The University of Canterbury. 
the built-up area and does not appear to predominate in any one area. Fig. 2 shows the scatter of damage to chimneys in Christchurch. No cases were reported of stock beine thrown off shelves in shops.

The distribution of chimney damage throughout the area is shown in fig. 2。 Damage of other types followed a similar pattern with no apparent preponderance in any one part of the built-up area.

\section{Table 1}

\begin{tabular}{|c|c|}
\hline Type of Damage & $\begin{array}{l}\text { Extent of Damage as } \\
\text { percentage of total }\end{array}$ \\
\hline $\begin{array}{l}\text { Chimneys } \\
\text { Cracking to walls and ceilings } \\
\text { Roofs (tiles etco) } \\
\text { Exterior } \\
\text { Foundations } \\
\text { Glass } \\
\text { Brick walls } \\
\text { General } \\
\text { Miscellaneous }\end{array}$ & $\begin{array}{l}42 \% \\
28 \% \\
7 \% \\
4 \% \\
2 \% \\
3 \% \\
3 \% \\
3 \% \\
7 \% \\
4 \%\end{array}$ \\
\hline
\end{tabular}

\section{Detailed description of damage}

\section{(a) Conmercial Buildings}

Damage was very slight considering the extent of the commercial areas and the apparent lack of seismic resistance of some older masonry buildings。

In a number of older brick buildings mortar was shaken loose from the joints by the vibration of the earthqualie. The dancer here is thet this may be one sign that the mortar has perished and no loneer acts to bond the bricks together. In this case these buildings would be serious earthqualse hazards should Christchurch experience an enrthcluake of similar or greater intensity. While it is known that there are bady cracked brick parapets on a number of buildings, only one parapet was further damaged to the extent that part of it collapsed。 The particular building was of two-skin brickwork and 70-80 years old。

Only two of the many modern, new buildings appear to have been damaged in any way. These buildings were fully designed to the New Zealand building code and the damage was confined to cracking of masonry panels。 The Government Life Buildirig is a concrete encased steel building with glazing on the South and East Walls and brick infill panels on the North and West Walls. Hairline cracks appeared in $\frac{1}{4}$ inch thick plaster on the north walls at ceiling level from the second floor upwards. The third and fourth floors were the most affected, with cracking extending around to the west side. It appears that the cracks were present before the earthquake and the on 1 y true earthquake damage was a small amount of loose plaster that was shaken down by the vibration and the fretting of the mortar joints with the slight earthquake movement. The damage has been considered to be not worth repairing at this stage. No glazing in the building was even cracked。

The other building which suffered some damage was the Bank of New Zealand. Ilere some superficial cracking occurred in block infill panels, adjacent to the concrete encased steel columns. In addition, 


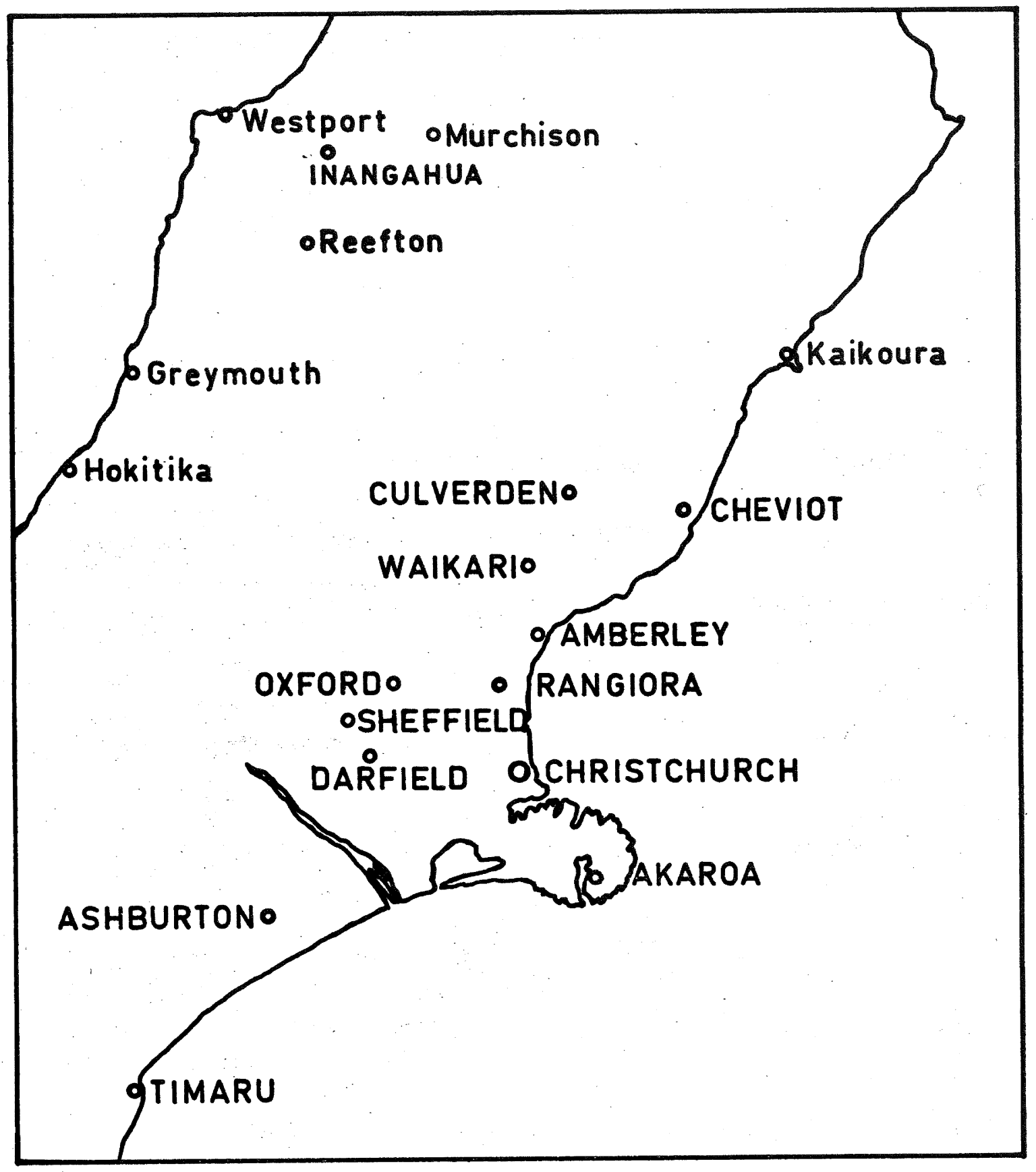

FIGURE 1. The Canterbury area in relation to Inangahua and the West Coast. 


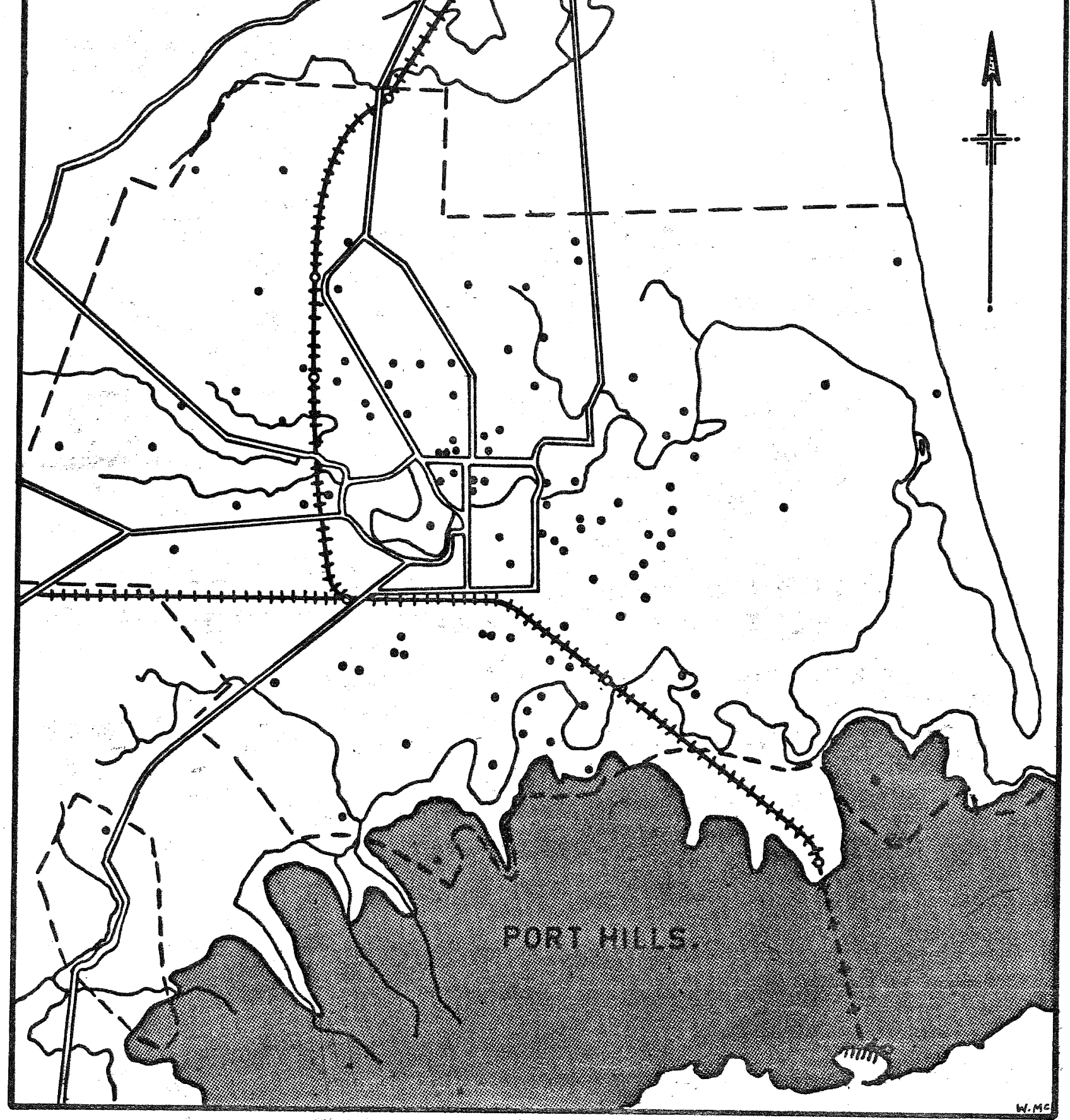

FIGURE 2. Distribution of chimney damage in the Christchurch area. (Dots indicate damaged chimneys.)

(Dash line indicates extent of urban area.) 
there was some hairline cracking of in-situ concrete and a small amount of cracked plaster.

A few other reports of minor cracking have been made but these have not been verified to date.

(b) Private Dwellings

Damage to walls and ceilings was partly a result of plaster cracking, which in some cases ruined wallpaper as well. Unfortunately, the available records do not show whether this interior wall and ceiling damage occurred more in the flexible weatherboard houses rather than the stiffer masonry veneer houses. A number of masonry veneer houses did suffer cracking damage to the outside walls。

Roof damage is not fully detailed in the claim records, though it would appear that most of the damage occurred with tile roofs。

There were many cases where some cracling of parts of the building existed before the earthquake and here the cracks were merely extended by the vibration. One two storey house which suffered damage was about 70 years old and not in a very good condition before 24 th May. The effect of the earthquake was merely to accelerate its ageing.

\title{
(c) Roads and Bridges
}

No damage was reported concerning bridges. The only road damage observed after the earthquake were a number of depressions in State Highway 7 near the top of the Lewis Pass, on the Canterbury side. These were not fully caused by the earthquake as they had also occurred previously。

\section{DAMAGE FROM GREYMOUTH TO HOKITIKA}

\author{
P. D. Anderson* and T. W. J. Osborne**
}

Greymouth is approximately $100 \mathrm{~km}$ from the epicentre and Hokitika approximately $130 \mathrm{~km}$. The intensity of damage changed significantly over this distance, there being considerable damage at Greymouth but only slight damage at Hokitika. Some Hokitika commercial buildings of construction similar to buildings which suffered moderate damage in Greymouth had virtually no damage at all.

The first author inspected only 4 commercial buildings which suffered structural damage, and 3 of these were for trivial amounts.

Some brickwork out-buildings in Hokitika which were almost in a state of collapse before the earthquake were apparently no worse off following it.

The incidence of cracked or fallen chinmeys was much less in Hokitika than in Greymouth though the damage was still significant.

Embankments at approaches to bridges were all observed to have slumped, but the amount was very slight by the time Hokitika was reached, compared with significant slumping in the Greymouth area.

++ Insurance Assessor 